IZA DP No. 5252

Foreign Acquisitions, Domestic Multinationals, and R\&D

Roger Bandick

Holger Görg

Patrik Karpaty

October 2010 


\title{
Foreign Acquisitions, Domestic Multinationals, and R\&D
}

\author{
Roger Bandick \\ University of Aarhus \\ Holger Görg \\ Kiel Institute for the World Economy, \\ University of Kiel and IZA \\ Patrik Karpaty \\ Örebro University
}

\section{Discussion Paper No. 5252 \\ October 2010}

\author{
IZA \\ P.O. Box 7240 \\ 53072 Bonn \\ Germany \\ Phone: +49-228-3894-0 \\ Fax: +49-228-3894-180 \\ E-mail: iza@iza.org
}

\begin{abstract}
Any opinions expressed here are those of the author(s) and not those of IZA. Research published in this series may include views on policy, but the institute itself takes no institutional policy positions.

The Institute for the Study of Labor (IZA) in Bonn is a local and virtual international research center and a place of communication between science, politics and business. IZA is an independent nonprofit organization supported by Deutsche Post Foundation. The center is associated with the University of Bonn and offers a stimulating research environment through its international network, workshops and conferences, data service, project support, research visits and doctoral program. IZA engages in (i) original and internationally competitive research in all fields of labor economics, (ii) development of policy concepts, and (iii) dissemination of research results and concepts to the interested public.
\end{abstract}

IZA Discussion Papers often represent preliminary work and are circulated to encourage discussion. Citation of such a paper should account for its provisional character. A revised version may be available directly from the author. 
IZA Discussion Paper No. 5252

October 2010

\section{ABSTRACT \\ Foreign Acquisitions, Domestic Multinationals, and R\&D*}

The aim of this paper is to evaluate the causal effect of foreign acquisition on R\&D intensity in targeted domestic firms. We are able to distinguish domestic multinationals and nonmultinationals, which allows us to investigate the fear that the change in ownership of domestic to foreign multinationals leads to a reduction in R\&D activity in the country, as headquarter activities are relocated to the new owner's home country. We use unique and rich firm level data for the Swedish manufacturing sector and different micro-econometric estimation strategies in order to control for the potential endogeneity of the acquisition dummy. Overall, our results give no support to the fears that foreign acquisition of domestic firms lead to a brain drain of R\&D activity in Swedish MNEs. Rather, this paper finds robust evidence that foreign acquisitions lead to increasing R\&D intensity in acquired domestic MNEs and non-MNEs.

JEL Classification: F23

Keywords: domestic multinationals, foreign acquisitions, $R \& D$

Corresponding author:

Holger Görg

Wirtschafts- und Sozialwissenschaftliche Fakultät

Institut für Volkswirtschaftslehre

Christian-Albrechts-Universität zu Kiel

Olshausenstraße 40

24118 Kiel

Germany

E-mail: holger.goerg@ifw-kiel.de

\footnotetext{
* We are grateful to participants at the Aarhus - Kiel International Economics Workshop and the ETSG 2009 in Rome for helpful comments. Holger Görg is also affiliated with GlobID at Aarhus School of Business / University of Aarhus. He gratefully acknowledges financial support through the European Commission, Research Directorate General as part of the 7th Framework Programme, Theme 8: Socio-Economic Sciences and Humanities, Grant Agreement no: 244552.
} 


\section{Introduction}

The debate on the home country effects of multinational activity is still lively. While the popular media and the general public tend to associate outward investment by multinationals necessarily with economic losses (in employment, wages, etc.), much economic research has found that this is not the case. Indeed, studies find that multinational firms have an advantage over others in terms of efficiency and productivity, which can be further exploited abroad. Even if they relocate activity from the home country abroad, they tend to concentrate on high value / high skill headquarter activities at home, and overall there is little evidence that they substitute host country for home country employment (e.g., Blomström, Fors and Lipsey, 1997; Barba Navaretti et al., 2006; Hijzen et al., 2009).

The recent wave of cross-border mergers and acquisitions has added a new dimension to this debate. The question that is discussed now is: What will happen to the domestic multinationals, and in particular their headquarter activities, once they are acquired by a foreign owner? In Sweden, the country to which our empirical analysis pertains, this has been an important issue. Former flagship Swedish multinationals such as Volvo, Saab, Asea and Astra were acquired by foreign owners and, therefore, are no longer Swedish. Does this change in ownership imply that high skill intensive headquarter activities will now be no longer carried out in Sweden, but in the headquarters of the foreign acquirer in the US or Switzerland?

This is an important question that is not only of academic interest, but also has strong policy implications. Headquarter activities in multinationals are high skill activities such as $R \& D$ and management. R\&D may be the most important here, as this is an activity that is likely to generate positive externalities. Hence, relocation of the R\&D activity abroad may lead to potential welfare losses (Krugman, 1991).

In standard models of the multinational enterprise, such as Markusen (2002) firms can potentially separate headquarter and production activities. The former are activities such as $R \& D$, marketing, management, and they are assumed to be more relatively skill intensive than production. Assuming further that countries may differ in their relative factor endowments, firms will separate HQ and 
production if countries are sufficiently different. In that case, HQs will be located in the relatively skill abundant, production in the relatively skill scarce country. ${ }^{1}$

The question we address in this paper is: What happens to the HQ activities, or more specifically, R\&D activity in Sweden, once the multinational gets taken over by a foreign multinational, which, by definition, has its headquarter activities in its own home country? Will the R\&D of the firm be relocated to the home country of the new owner, depleting Sweden of its high skill activity? Or will the $R \& D$ location be maintained and perhaps even extended as a result of the foreign takeover? And, how do these effects compare to the R\&D effects of acquisitions of domestic nonmultinationals - is there a special "multinationality effect”?

Standard theory has little to say on this, as they treat all multinational activity as greenfield activity, i.e., setting up new facilities abroad, rather than acquiring already existing plants. However, recent models, such as, Nocke and Yeaple (2008) consider explicitly the choice between greenfield investment and merger \& acquisition. They posit that acquisition will take place if firms intend to access the assets held by the acquisition target, and if there is complementarity between assets held by the acquirer and by the target. While Nocke and Yeaple do not explicitly consider the postacquisition performance in the target plant, one hypothesis in line with their intuition may be that it depends on the nature of the complementarity/substitutability of the HQ and especially R\&D activities in the target and acquirer country. If $R \& D$ activities are complementary then they may be left in their respective countries according to their respective expertise. If the activities are however strong substitutes, it is likely that the acquirer will relocate all HQ and R\&D activities to its home country in order to avoid wasteful duplication of activities in the two countries.

Bertrand et al. (2008) also develop a theoretical model which highlights the role of complementarities. In their model, the foreign acquirer has incentives to increase investments in new $R \& D$ in order to make rivals less aggressive in their investment behavior. They show that the complementarity between the $R \& D$ assets of the foreign owner and the domestic firm must be high for an acquisition to take place. The better the initial quality of the R\&D assets in the domestic

\footnotetext{
${ }^{1}$ Indeed, Markusen (1998) cites Sweden as a prominent example for his model, where the country will host HQ activities of multinational firms, while production is undertaken in affiliates abroad. Country size also plays a role in Markusen (2002), though this can be neglected for our purposes. Ekholm and Hakkala (2007) present a related model, which also allows for agglomeration forces in production as well as R\&D activity.
} 
firm, the higher is the alternative costs for not acquiring it. Another result is that post-acquisition, the acquirer has a strong incentive to expand R\&D activities in the target firm.

These theoretical ideas are both intuitive and practically relevant. As, for example, the recent discussions of the relationship between GM and Opel show, one reason for GM to try to hold on to Opel is the strong R\&D expertise in the German HQ as relates to small and medium sized vehicles, whereby GM’s expertise is rather in larger motor cars. Hence, the R\&D activities in the two firms are likely to be complementary, and hence, may be left in their respective countries. This is the case in this example, where Opel has extensive R\&D facilities in Europe, while GM also undertakes R\&D in the US. Similar considerations about asset and R\&D complementarity seem also to be important for the Chinese car maker Geely’s intentions to acquire Volvo from Ford.

We look at the effects of foreign acquisitions on R\&D in the target firm empirically. We do not provide a direct test of a specific theoretical model, as an empirical test would need detailed data on the nature of HQ activities in acquirer and target. Unfortunately, we do not have such data available. Rather, we use this theoretical discussion as a motivation for our empirical analysis, as it shows that there is a rationale for our research question, since the expected effect is ambiguous and, hence, merits empirical investigation.

On the empirical side, our paper relates to two strands of literature. Firstly, there is a literature on the relationship between M\&As in general, and foreign acquisitions in particular, on $R \& D$ in the host country (e.g., Cassiman et al, 2005; Bertrand and Zuniga, 2006). This literature, however, does generally not look at the effect on the target firm, but rather overall $R \& D$, and also does not specifically look at the experience of domestic multinationals. The second strand of literature is on the effects of foreign acquisitions on the target firm. Here, studies generally look at productivity, employment or wages (e.g., Harris and Robinson, 2002; Girma and Görg, 2007; Huttunen, 2007). More closely related to our paper, Bertrand (2009) investigates empirically post acquisition R\&D performance in target firms using French data. However, he does not distinguish targets into multinationals and non-multinationals which, as we argue, is a highly policy relevant issue. Also, Bertrand et al. (2008) provide some evidence that acquisitions are associated with higher $R \& D$ intensity than greenfield investments. While their theoretical model also has predictions about the 
post-acquisition effect on R\&D (as discussed above), they do not have data to test this empirically. Our paper specifically looks at the post-acquisition R\&D performance in the target firm.

We study in detail the acquisitions of domestic firms by foreign owners, and examine in particular the implications for R\&D activity in the target firms using a number of different estimation techniques to establish robust results. We use recent unique detailed firm level data for Sweden to investigate the extent of $R \& D$ undertaken in the Swedish firms before and after acquisition. We look at the timing of these effects, considering changes in R\&D activity one, two and three years after the acquisition took place. Most importantly, we also contrast the effect of acquisition on $\mathrm{R} \& \mathrm{D}$ for domestic multinationals and on domestic non-multinationals.

This, thus, addresses directly the question of what happens to an important aspect of HQ activities (R\&D) after a domestic multinational is taken over by foreign owners. Is it different than the acquisition of a purely domestic (non-multinational) firm? One may perhaps expect differences, as R\&D activities in multinationals are likely to present HQ activities that may be expected to be more extensive than that of a purely domestic firm, as the multinational serves additional foreign markets (Markusen, 1998). We show this to be the case in our summary statistics in Table 3. Hence, the question as to whether $\mathrm{R} \& \mathrm{D}$ in the foreign acquirer and the domestic target are complements or substitutes may be even more important for the case of Swedish multinationals and any acquisition effects may be more pronounced. To the best of our knowledge, we are to first paper to explore this highly policy relevant issue in any detail.

Sweden is an interesting case to analyze in this context. As our data show (see Table 1), the number of foreign firms and the share of employment in these firms has steadily increased over the last decades. Sweden also traditionally has had a number of well known domestic multinationals, some of which have been acquired by foreign owners in the recent past. It is, therefore, particularly interesting to see what happened to one particular headquarter service, namely R\&D, after the incidence of foreign acquisitions.

In the empirical analysis, we identify the acquisition effect in a difference-in-differences set up. We take particular account of the potential endogeneity of the acquisition decision by firstly implementing an instrumental variables approach. Furthermore, we check the robustness of the IV 
approach with estimations based on combining difference-in-differences with propensity score matching techniques.

To preview our results, we find robust evidence that there is on average no negative effect from acquisition on R\&D performance in Swedish plants. Rather, the evidence suggests that there are strong positive effects, depending on the specification. We do not find any evidence that foreign acquisition of domestic multinationals leads to a relocation of $\mathrm{R} \& \mathrm{D}$ activity abroad and subsequently reductions of R\&D in Sweden. In the light of Nocke and Yeaple (2008) and Bertrand et al. (2008), one possible interpretation of these results is that they are in line with the idea that $\mathrm{R} \& \mathrm{D}$ in the parent and target firm are complementary.

The rest of the paper is structured as follows. Section 2 describes the dataset and presents some preliminary empirics on the link between foreign acquisition and R\&D. Section 3 describes the empirical methodology and Section 4 discusses the results. Section 5 concludes.

\section{Data and description}

The data are from Statistics Sweden (SCB) and the Swedish Agency for Growth Policy Analysis, hereafter Growth Analysis (former Swedish Institute for Growth Policy Studies, ITPS). The dataset covers all manufacturing firms that operate in Sweden with at least 50 employees for the period 1993-2002. The register information used in this analysis has been obtained from several sources and has been merged using unique identification numbers. The Structural Business Statistics (SBS) gives us information by firm on sales, investments, $R \& D,{ }^{2}$ various inputs, and whether it is foreign or domestic owned. Foreign owned firms (foreign MNEs) are firms where foreigners possess more than $50 \%$ of the voting rights. The Growth Analysis survey data provides information on all Swedish controlled enterprise groups with subsidiaries abroad. A Swedish MNE is then a

\footnotetext{
${ }^{2}$ In the SBS database firms should specify their yearly R\&D spending within specific intervals of SEK; $1-249000$, 250 000-999 000, 1-4.9 million, 5-9.9 million and then 10 million or more. If the yearly R\&D expenditures exceed 10 million SEK, the firms should specify the exact amount. The R\&D information covers firms that have a minimum of one employee who is active in any R\&D activity at $50 \%$ of a full time employment. Moreover, the SBS R\&D statistics are retrieved annually and it is compulsory for firms to reply. R\&D is not evenly distributed across industries.
} 
domestically owned firm that is part of an enterprise with affiliates abroad. ${ }^{3}$ Non-MNE firms are firms that are neither Swedish MNEs nor foreign MNEs. By using the information on ownership status we can define foreign acquisition of a domestic MNE as a change in ownership indicator from a domestic MNE to foreign and foreign acquisition of a domestic non-MNE as a change in ownership indicator from a domestic non-MNE to foreign. ${ }^{4}$

Since R\&D data are only available for firms with at least 50 employees we have to restrict the analysis to firms above this threshold. This should not prevent us from drawing general conclusions for the Swedish manufacturing sector since data cover more than three fourth of total value added in the manufacturing sector. ${ }^{5}$ Moreover, two-thirds of all private R\&D is concentrated to the large top ten R\&D firms, see Karpaty and Tingvall (2009). This should motivate an analysis on larger firms only.

From Table 1 we see that the number of foreign MNEs and employment in these firms have increased during the whole period in manufacturing industries. The opposite pattern is observed for Swedish MNEs which may indicate that the main target for foreign acquisitions of Swedish firms during the 1990's have been large Swedish MNEs, such as Astra, Pharmacia, Volvo Car, Saab Automobile.

\section{Table 1 here}

We find some support for this hypothesis in Table 2, by, e.g, taking a closer look at the noticeably large changes of foreign presence in the Chemical industry and Motor vehicles. Table 2 provides the distribution of the number of firms between 22 industries at the two digit level in 1993 and 2002. The distribution of foreign and domestic MNEs is characterized by large heterogeneity between different industries and over time. Consistent with the rising presence of foreign firms in the Swedish economy over time, the observed trend is upwards sloping across these different measures. It appears that the presence of foreign firms decreased between 1993 and 2002 in only

\footnotetext{
${ }^{3}$ The first year in which we can distinguish Swedish MNEs from non-MNEs is 1993 and explains why our analysis begins in 1993.

${ }^{4}$ Firms that switch between domestic and foreign ownership more than once over the period are not included in the sample. Also, firms that disappear from the sample one year and reappear in later years are excluded.

${ }^{5}$ Karpaty (2006) shows that in 1997, firms with at least 50 employees constituted about $77.5 \%$ of total employment and $82 \%$ of total value added in the manufacturing sector.
} 
five out of 22 industries (in two other industries there was no foreign presence at all). The opposite pattern is found for domestic MNEs whose share of all firms fell in eleven out of 22 industries during the same period. This again reflects the large extent of foreign acquisitions of domestic MNEs.

\section{Table 2 here}

Table 3 shows differences in mean values of some firm characteristics between domestic and foreign-owned firms in 2002. We compare unweighted averages and use t-statistics for any possible difference between foreign and domestic firms for each variable. What seems to matter in general is not whether the firm is foreign or domestically owned but whether the firm is multinational or not (see also Criscuolo and Martin, 2010). There is a statistically significant difference in all variables when we compare Swedish MNEs and non-MNEs. Hence, foreign and Swedish MNEs are more R\&D intensive, larger, use more skilled labor, are more productive and pay higher wages than their non-multinational counterparts. This is in line with the idea, pointed out in the introduction, that Swedish multinationals have more extensive HQ activities in Sweden than purely domestic firms. Comparing Swedish and foreign MNEs we find that there is no statistically significant difference in terms of employment, sales, labor productivity, capital and skill intensity between the two firm types. However, it seems clear that foreign owned firms invest more in $R \& D$ and pay higher wages than domestic multinationals.

\section{Table 3 here}

We investigate in what follows whether this higher $R \& D$ intensity, defined as the ratio of expenditures by a firm on research and development to the firm's sales, in foreign MNEs is due to post-acquisition increases, or whether it may be explained by foreign firms targeting high $R \& D$ intensive domestic firms when choosing takeover targets. To see how important foreign acquisitions were in the Swedish manufacturing sector, Table 4 reports the number of foreign acquisitions in the sample used in the analysis for the period 1993-2002. ${ }^{6}$

\section{Table 4 here}

\footnotetext{
${ }^{6}$ Note that these are acquisitions rather than mergers. Our definition of an acquisition is that at least 50 percent of the voting rights are acquired by a foreign owner.
} 
In Table 5 we test the hypotheses that target and non-target Swedish firms have different characteristics before and after acquisitions using the sample of acquired and non acquired firms (i.e., disregarding firms that are always foreign-owned). It appears that acquired firms invest more in R\&D one year prior to an acquisition. There are also other important differences pre- and post acquisitions. Target firms are in general larger in terms of employment and sales. They are also more productive than non-target firms. At the same time target firms have higher capital intensities - both in terms of physical capital and skill intensity (human capital intensity). According to Table 6 most of these differences are maintained or even strengthened under the new ownership post acquisition. Human capital intensity and average wages do however decline in foreign owned firms post acquisitions. Overall this suggests that foreign ownership does matter. In the next section we will go beyond these mean values and analyze the effects of foreign acquisition on R\&D intensity post acquisition more thoroughly. In order to control for initial differences we will also employ instrumental variables and propensity score matching techniques in order to identify an effect of foreign acquisition on R\&D intensity.

\section{Table 5 here}

\section{Methodology}

The aim of this paper is to evaluate the causal effect of foreign acquisition on R\&D intensity in a targeted domestic firm. We are also interested in whether this effect is different depending on whether the target is a domestic multinational or not. In line with previous literature (e.g., Heckman et.al., 1997 and Deheija and Wahba, 2002), we define the average effect of acquisition of the acquired firms as:

$$
E\left\{y_{t+s}^{1}-y_{t+s}^{0} \mid A F_{i t}=1\right\}=E\left\{y_{t+s}^{1} \mid A F_{i t}=1\right\}-E\left\{y_{t+s}^{0} \mid A F_{i t}=1\right\}
$$

where, $A F_{i t} \in\{0,1\}$ is an indicator of whether firm $i$ is acquired by a foreign firm in time period $t$ and $y_{i t+s}^{1}$ and $y_{i t+s}^{0}$ denote the outcome variable (in our case R\&D intensity) following the acquisition year $t$ for acquired and non-acquired firm, respectively. However, the problem is that $y_{i t+s}^{0}$ is by definition unobservable. We have then to construct the counterfactual i.e. what would the 
R\&D intensity in acquired firms have been, on average, had they not been acquired. As a proxy we can use the average R\&D intensity of firms that still are domestically owned, $E\left\{y_{i t+s}^{0} \mid A F_{i t}=0\right\}$. However, differences in characteristics and performance between acquired and non-acquired firms in the years before acquisition could bias the estimates of the causal effect of foreign acquisition. Also, there are strong reasons to believe that the acquisition dummy, $A F_{i t}$, is endogenously determined. We use several methods to deal with these problems.

The first strategy to estimate the impact of ownership change on the growth rate in R\&D intensity in acquired firms, is to use difference-in-difference (DiD) estimation given by the following equation:

$$
\beta_{t+s}=\left(y_{t+s}^{A}-y_{t-1}^{A}\right)-\left(y_{t+s}^{C}-y_{t-1}^{C}\right)
$$

The first part of the right-hand side of equation (2) determines the difference in our outcome variable between the pre and post acquisition period for the acquired firms $A$ and the second part determines the difference for the same variable and time period for the non-acquired firms C. We obtain an estimate for $\beta_{t+s}$ by using the following regression:

$$
\Delta y_{i t}=y_{i t+s}-y_{i t-1}=\beta A F_{i t}+d_{t}+\mu_{i}+\varepsilon
$$

where $\Delta y_{i}$ is growth in $\mathrm{R} \& \mathrm{D}$ intensity between time period $\mathrm{t}-1$ and $\mathrm{t}+s ; s \in\{1,2,3\} . A F_{i t}$ is a dummy variable switching from acquired firms from 0 to 1 after the acquisition year $t$. It is 0 for non-acquired firms C. $d_{t}$ is a vector of time dummies, and $\mu_{i}$ is a firm specific time invariant effect. The estimate of $\beta$ yields the average percentage point change in the growth rate in $R \& D$ intensity that can be attributed to foreign acquisition.

However, the estimation of $\beta$ in equation (3) rests on the assumption that domestic firms taken over by foreign MNEs are randomly acquired. This is, arguably, a strong assumption. In order to control for the possible endogeneity we utilize, as a second estimation strategy, an instrumental variable approach by using the predicted probability of being acquired as an instrument. This is shown to be a valid strategy by Vella and Verbeck (1999) and was implemented in the context of acquisitions by 
McGukin and Nguyen (2001) and Bandick and Görg (2010). This may be an appropriate instrument as it is likely to be highly correlated with the actual acquisition. However, given that not all firms with a similar takeover probability are actually acquired, the predicted probability is less likely to be correlated with the error term in equation (5). Of course, we test for validity and relevance of the instruments using standard tests.

In line with this approach, we generate a firm's predicted value of being acquired from the following probit model:

$$
P\left(A F_{i t}=1\right)=F\left(X_{i t-1}, I_{j}, T_{t}\right)
$$

where again $A F=1$ if a domestically owned firms in year $t-1$ become foreign owned in year $t$. $X_{i t-1}$ is a vector of relevant firm specific characteristics in year $t-1$ which may affect the firms' probability of being acquired in year $t$. $I$ and $T$ control for fixed industry and time effects. The generated value for the acquisition dummy is then used as an instrument in equation (3):

$$
\Delta y_{i t}=y_{i t+s}-y_{i t-1}=\beta A F^{I V}{ }_{i t}+d_{t}+\mu_{i}+\varepsilon
$$

The instrumental variables approach of course hinges on the validity and relevance of the excluded instruments in the first step. We also employ additional strategies that do not rely on such exclusion restrictions being imposed, namely, combined differences-in-differences propensity score matching (see Blundell and Costa Dias, 2000). The idea of the propensity score matching (PSM) approach is to find for every foreign acquired firm, a similar firm that has remained in domestic hands and from which we can approximate the non-observed counterfactual event. Thus, the matching technique enables us to construct a sample of acquired and non-acquired firms with similar pre-acquisition characteristics $X$, e.g. productivity, wages, size etc. Conditional on these characteristics we estimate the probability (or propensity score) of being acquired by a foreign firm using the same probit model as in equation (4). 
Once the propensity scores are calculated, we can select the nearest control firms in which the propensity score falls within a pre-specified radius as a match for an acquired firm. ${ }^{7}$ Moreover, we check whether the balancing condition is verified, that is each independent variable does not differ significantly between acquired and non-acquired firms. Another condition that must be fulfilled in the matching procedure is the so-called common support condition. ${ }^{8}$

We use the propensity score matching for two different set ups. The first is what may be called an “indirect" approach of PSM where we use the propensity score to select a matched sample of acquired and "nearest neighbour" non-acquired firms. We then estimate equation (3) on this matched sample of firms. This approach was recently applied in the international economics literature by Greenaway and Kneller (2007) and Bandick and Görg (2010).

The second approach is the "direct” matching estimator as described by Blundell and Costa Dias (2000) and recently employed by, for example, Arnold and Javorcik (2009) and Girma and Görg (2007). Let $p_{i}$ denote the predicted probability of being acquired (generated using equation (4)) for firm $i$ in the group of acquired firms (A) and $p_{j}$ is the predicted probability of being acquired for plant $j$ in the control group (C). $\Delta y$ is the difference between the average $R \& D$ intensity before and after the change of ownership. Then the difference-in-differences matching estimator can be expressed as:

$$
\beta=\sum_{i \in A}\left(\Delta y_{i}-\sum_{j \in C} g\left(p_{i}, p_{j}\right) \Delta y_{i}\right)
$$

where $\mathrm{g}($.$) is a function assigning the weights to be placed on the comparison firm j$ while constructing the counterfactual for acquired firm $i$. In the case of nearest neighbor matching as employed in this paper, this function selects a $p_{j}$ as close to $p_{i}$ as possible.

\footnotetext{
${ }^{7}$ This is done using the "caliper" matching method. The procedure we utilize to match acquired and non-acquired firms is the PSMATCH2 routine in Stata version 10 described in Leuven and Sianesi (2003). In our analysis, the pre-specified radius is set to 0.001 . In the appendix, Table A1 presents the results of estimating two alternatives of equation (4). Column (i) is the model used for the estimations reported in the main part of the paper, column (ii) presents a robustness check. Tables A2 and A3 report the resulting propensity scores and tests of the balancing conditions.

${ }^{8}$ Note that some acquired firms may be matched with more than one non-acquired firm, while acquired firms not matched with a non-acquired firm are excluded. Eventually, we end up with a sample, henceforth denoted the matched sample which consists of 227 acquired firms and 2,842 non-acquired firms.
} 
Before turning to estimating the effects of foreign acquisitions on R\&D, we look at the characteristics of the target firm that are correlated with foreign acquisition. To do so, Table A1 in the appendix presents the results of estimating the probit for equation (4). The estimates indicate that the more productive, skill- and capital intensive the domestic firms are, the more likely they are to be acquired by foreign MNEs. Moreover, firms in industries with a large foreign presence are more likely to experience an acquisition.

\section{Empirical results}

We now turn to identifying the effect of foreign acquisition on domestic R\&D activity. As discussed in the previous section, we use alternative estimation strategies in order to evaluate the relationship between the foreign acquisition of domestic firms and R\&D activity. First, we present the results from estimating equation (3) with OLS in order to establish a benchmark. This estimator of course disregards the firm specific effect $\mu_{i}$. Hence, we then estimate the equation using a fixed effects (FE) technique. In this set up, $\beta_{1}$ can be interpreted as the difference-in-differences estimate of the effect of foreign acquisition on R\&D in the target firm. Results are shown in Table 6.

In the first two columns we report the results of estimating equation (3) for the growth rate of R\&D intensity for the period one year before and one year after foreign acquisition. In column (iii) to (iv) and (v) to (vi) we expand our analysis of the growth rate of R\&D intensity to also include the difference between $t-1$ and $t+2$ and $t-1$ and $t+3$, respectively. These baseline results indicate that foreign acquired firms have had larger growth in R\&D intensity in the years following takeover as compared to non-acquired firms. The difference in the growth rate of $R \& D$ intensity between acquired and non-acquired firms one year after the takeover is around 5 percent. This increases to 8 percent two years after the foreign takeover while it returns to around 5 percent in the third postacquisition year.

\section{Table 6 here}

These results provide initial evidence that fears about foreign acquisitions leading to less $R \& D$ activity in the target firms appear to be misplaced. A possible explanation for these positive effects is that, as highlighted by Nocke and Yeaple (2008) and Bertrand et al. (2008), R\&D in the home 
and target country are complements and, hence, an acquirer will find it beneficial to expand R\&D in the target country. An alternative, not mutually exclusive explanation is that the foreign acquisition leads to an inflow of new technology, which boosts R\&D activity. Unfortunately, with the data at hand we are not able to discriminate between such alternative explanations. The focus of the further analysis is, rather, to establish the robustness of a causal relationship between foreign acquisitions and $\mathrm{R} \& \mathrm{D}$, and to investigate whether there are differences in effects depending on whether the target firm is itself a multinational or not.

Of course, unobserved differences in firm characteristics and performance between acquired and non-acquired firms in the years before acquisition could bias the estimates of the causal effect of foreign acquisition on R\&D in the target. The information in Table 5 and the result from the probit model in Table A1 provide us with some evidence that this may indeed be a problem in our case, as firms with "good” characteristics and performance are more likely to be targeted for acquisitions by foreigners. These characteristics are likely to be correlated with $R \& D$ activity, hence, not considering this endogeneity problem implies that we may falsely attribute the post-acquisition firm performance to the foreign takeover.

To overcome this problem, we employ a number of alternative estimation strategies as outlined in Section 3. We first estimate the DiD model in equation (5) which instruments for the acquisition dummy in order to allow for endogeneity of this variable. We use the predicted probability of foreign acquisition (as in Table A1) as an instrument. In order to allow us to test for instrument validity based on overidentification restrictions, we include the share of acquisitions in an industry as additional instrument. The rationale is that firms are more likely to be targeted for acquisitions in sectors with high acquisition activity. However, given the dispersion of R\&D activity within a sector, this variable is unlikely to be correlated with the error term in equation (5), conditional on the other control variables included in the instrumental variables regression.

Table 7 presents the results. The Sargan test reported in the table suggests that we have a valid instrument in column (i), but that the instrument is more problematic in columns (ii) and (iii). The F-test from the first stage regression shows in all cases that the instrumental variables candidates are relevant instruments, in the sense of being strongly correlated with the acquisition dummy. Furthermore, in this linear regression framework we can test for possible endogeneity using a 
Hausman test; the test statistics support the notion that foreign acquisitions might be endogenous to the process of $R \& D$ growth.

The results in column (i) show that one year after the acquisition, acquired firms have had significantly higher growth in R\&D intensity as compared to non-acquired firms. Column (ii), shows the growth rate in $R \& D$ intensity between the period one year before and two years after the acquisition. We still find a positive effect, although the coefficient is statistically insignificant at conventional levels. Column (iii) also shows a positive acquisition effect on R\&D intensity. The instrumental variables estimation, hence, underline our earlier results in Table 6, namely, the foreign acquisitions generally tend to have positive effects on R\&D activity of the takeover targets. ${ }^{9}$

\section{Table 7 here}

This approach, of course, hinges on the validity and relevance of the excluded instruments in the first step. In what follows, we use two alternative strategies based on propensity score matching, which do not rely on such exclusion restrictions being imposed. Table 8 reports the results of estimating the difference-in-differences model in equation (3), on a matched sample of acquired and non-acquired firms obtained by implementing the propensity score matching approach. ${ }^{10}$ The estimates show once again that the growth in $R \& D$ intensity is much higher in foreign acquired firms than in non-acquired firms. From column (i)-(ii) we can observe that one year after the takeover the R\&D intensity grow around 5 percent more in acquired firm as relative to nonacquired firms and as shown in column (iii)-(iv) and (v)-(vi) around 8 and 6 percent two and three years after the takeover, respectively. ${ }^{11}$

\footnotetext{
${ }^{9}$ We also estimated alternative specifications of the acquisition probit equation (4) to check whether the results reported here depend on the process by which the instrument was generated. Specifically, we use an alternative instrument for the acquisition dummy generated from the second column in the probit regression in Table A1. The results of this are reported in Table A4 in the appendix. They underline that the results are robust to alternative definitions of the instruments. Note that this alternative instrument also passes the Sargan test of overidentification restrictions specifically in column (ii).

${ }^{10}$ The matched sample is obtained using the same variables as in column (i) in Table A1. Following the suggestion of Dehejia (2005), a further robustness check is to investigate the sensitivity of the matching estimates to minor changes in the propensity score model. If the results are not sensitive to such minor changes, the propensity score specification can be deemed robust and reliable. To do so, we have also used the probit in column (ii) to generate the propensity score. The results, not reported here but available upon request, are similar to those in Table 8 .

${ }^{11}$ Before matching firms together the sample consist of two subgroups: domestic firms acquired by foreign firms and a group of similar domestic firms that remained domestic during the period 1993-2002. We define the treatment group to be firms that sometime during the period become foreign owned. We exclude Greenfield operations and firms that
} 


\section{Table 8 here}

Finally, Table 9 shows the results of the "direct" difference-in-differences propensity score estimator as described in equation (6). Again, we find positive acquisition effects, although the estimate is not statistically significant for the three year difference. The point estimates are somewhat lower than in the previous estimations, suggesting that foreign acquisition implies a roughly 2.2 to 3.6 percent increase in the growth of $R \& D$ intensity in the target firm.

\section{Table 9 here}

Overall, these results suggest that foreign acquisitions in general have positive effects on $R \& D$ activity in the target firm. This may be due to additional technology transfer after acquisition, or to complementarity of R\&D undertaken in the home country of the foreign acquirer and the target firm. In the policy debate, particular attention is paid to what happens to headquarters, and in particular R\&D activity of domestic multinationals if they are taken over by a foreign firm. As pointed out in the introduction, this may be an important issue given that MNEs may be expected to have more extensive headquarter activities in Sweden. ${ }^{12}$ We now dig deeper into our data to investigate this. Specifically, to allow for different impacts of foreign acquisitions on R\&D intensity depending on whether a Swedish MNE or Swedish non-MNE is acquired, we add in equation (5) interaction variables, of the two firm type dummies multiplied with the instrumented acquisition dummy. The first interaction variable then captures the $\mathrm{DiD}$ between acquired Swedish MNEs and non-acquired firms while the second interaction variable captures the DiD between acquired non-MNEs and non-acquired firms.

Table 10 shows the results. We use similar probit models as in Table A1 to generate the IV for the dummies acquired Swedish MNEs and acquired Swedish non-MNEs. The results indicate that as compared to non-acquired firms, both targeted Swedish MNEs and non-MNEs have higher growth in R\&D intensity one year after the takeover. It seems also that targeted Swedish non-MNEs have higher growth in R\&D intensity two and three year after the acquisition as compared to nonacquired firms in the same period. However, there is no significant difference in R\&D intensity

\footnotetext{
became foreign owned before 1994 and firms that switch between domestic and foreign owned more than once. Moreover, only firms that survive at least four years in the panel are included in the analysis.

12 This is also reflected in the summary statistics in Table 3.
} 
growth between targeted Swedish MNEs and non-acquired firms two years after acquisition but in the third year after the takeover it seems that this difference is again positive and significant.

\section{Table 10 here}

To check whether the results in Table 10 are robust we first report in Table 11 estimations of the difference-in-differences model using the matched sample. The results for targeted Swedish nonMNEs are similar to these in Table 10. However, the difference in the growth in R\&D intensity between targeted Swedish MNEs and non-acquired firms seems in Table 11 is positive and significant both in the second and in the third post-acquisition year. Table 12, finally, reports the results of the "direct" DiD propensity score matching approach. This also shows that foreign acquisition has positive and statistically significant effects on R\&D activity in the target firm, irrespective of whether the target is a domestic multinational or not. ${ }^{13}$

\section{Table 11 and Table 12 here}

These results can be interpreted in the light of the theoretical ideas by Nocke and Yeaple (2008) and Bertrand et al. (2008). While we cannot test explicitly whether or not R\&D in the parent and target firm are complements or substitutes, our results are in line with the idea that they are complements. Hence, the foreign acquirer has an incentive to increase R\&D activity in the target firm post acquisition, as predicted by the models. We find robust evidence in the data that there is indeed such a positive effect on $R \& D$ after the foreign acquisition has taken place.

\section{Discussion and Conclusion}

Overall it would appear that the increased foreign presence in terms of foreign acquisitions of Swedish firms has had small and positive effects on the R\&D activity in these firms. The point estimates from our preferred difference-in-differences propensity score matching estimator suggest increases in $\mathrm{R} \& \mathrm{D}$ intensity by between 3 to 10 percent after foreign acquisition. These effects are

\footnotetext{
${ }^{13}$ As a final robustness check we estimated the DiD on the matched sample, and the difference-in-differences propensity score matching estimator on a balanced sample, i.e., only using firms that survived from $t-1$ through to $t+3$. The results, which are provided in the appendix, are very similar to what is reported in Tables 11 and 12.
} 
stronger for the acquisition of domestic non-multinationals than for Swedish multinationals. However, it is important to stress that even for the acquisition of Swedish multinationals, the effect on $R \& D$ is generally positive, never negative. Hence, our results suggest that fears that the acquisition of large Swedish multinationals by foreign owners may lead to a relocation of headquarter and in particular R\&D activities abroad appear unfounded.

These results are obtained from an econometric analysis of detailed firm level data for Sweden. The question we ask in this paper is whether or not there is a causal relationship between foreign acquisitions and R\&D intensity. We use different estimation strategies to control for selection bias in the evaluation of causal effects. First we use an instrumental variable (IV) approach treating the acquisition dummy as potentially endogenous and hence using a vector of instruments for this variable. In order to control the robustness of these results we proceed by using combinations of propensity score matching and DiD estimations.

Even though our empirical design is not aimed at testing directly a theoretical model, our results are broadly in line with theoretical ideas by Nocke and Yeaple (2008) and Bertrand et al. (2008). These models suggest that acquisition occurs if there is complementarity between the assets of acquirer and target. In our case it suggests complementarity between R\&D at home and in Sweden. As predicted by the theoretical models, if there is complementarity then foreign acquirers are likely to invest further in $R \& D$ in the acquisition target.

Our findings are highly policy relevant. The implication of our analysis is that foreign acquisitions can have beneficial effects for domestic R\&D activity. Hence, there is no need for fears and therefore no need for policy makers to start thinking about limiting international merger and acquisition activity. Quite the contrary: foreign acquisitions may be an important way to generate new knowledge and contribute to boosting the level of technology in the domestic economy. 


\section{References}

Arnold, J.M. and B.S. Javorcik (2009), Gifted kids or pushy parents? Foreign direct investment and plant productivity in Indonesia, Journal of International Economics, 79, 42-53

Bandick, R. and H. Görg (2010), Foreign acquisition, plant survival and employment growth, Canadian Journal of Economics, 43, 547-573.

Barba Navaretti, G., D. Castellani and A. Disdier (2006), How Does Investing in Cheap Labour Countries Affect Performance at Home? France and Italy, CEPR Discussion Paper 5765

Bertrand, O. (2009), Effects of foreign acquisitions on R\&D activity: Evidence from firm-level data for France, Research Policy, 38, 1021 - 1031

Bertrand, O. and P. Zuniga (2006), R\&D and M\&A: Are cross-border M\&A different? An investigation on OECD countries, International Journal of Industrial Organization, 24, 401-423

Bertrand, O., K-N. Hakkala, P-J. Norbäck and L. Persson (2008), Should countries block foreign takeovers of R\&D champions and promote greenfield entry? WP 772 IFN Stockholm.

Blomström, M., G. Fors and R. Lipsey (1997), Foreign direct investment and employment: Home country experience in the United States and Sweden, Economic Journal, 107, 1787-1797

Cassiman, B., M. Colombo, P. Gerrone and R. Veugelers (2005), The impact of M\&A on the R\&D process: An empirical analysis of the role of technological and market relatedness, Research Policy, 34(2), 455-476

Criscuolo, C. and Martin, R. (2009) Multinationals and US Productivity Leadership: Evidence from Great Britain, Review of Economics and Statistics, forthcoming.

Dehejia R. (2005), Program evaluation as a decision problem, Journal of Econometrics, 125, 141173 
Ekholm, K. and K. Hakkala (2007), Location of R\&D and high-tech production by vertically integrated multinationals, Economic Journal, 117, 512-543

Girma, S. and Görg, H. (2007), 'Evaluating the foreign ownership wage premium using a difference-in-differences matching approach’, Journal of International Economics, 72(1), 97-112

Greenaway, D. and R. Kneller (2008), Exporting, productivity and agglomeration, European Economic Review, 52(5), 919-939

Harris, R. and Robinson, C. (2002). 'The effect of foreign acquisitions on total factor productivity: Plant-level evidence from U.K manufacturing, 1987-1992', Review of Economics and Statistics, Vol. 84, pp. 562-568

Hijzen, A., S. Jean and T. Mayer (2009), The Effects at Home of Initiating Production Abroad: Evidence from Matched French Firms, Working Paper 2009/39, CEPII Paris.

Huttunen, K. (2007), 'The effect of foreign acquisition on employment and wages: Evidence from Finnish establishments', Review of Economics and Statistics, 89(3), 497-509

Karpaty, P. (2006) Does Multinationality Matter? Evidence from Swedish Firm Data, Applied Economics Quarterly, 52(2), 101-122

Karpaty, P. and Tingvall, P.G. (2009) Competition \& R\&D, Economics of Innovation and New Technology, forthcoming

Krugman, P.R. (1991), Geography and trade, MIT Press

Leuven, E. and Sianesi, B. (2003), PSMATCH2: Stata module to perform full Mahalanobis and propensity score matching, common support graphing, and covariate imbalance testing. Available at http://ideas.repec.org/c/boc/bocode/s432001.html. 
Markusen, J.R. (1998), Multinational firms, location and trade, The World Economy, 21(6), 733756

Markusen, J.R. (2002), Multinational firms and the theory of international trade, MIT Press

McGuckin, R.H. and S.V. Nguyen (2001), The impact of ownership changes: A view from labor markets, International Journal of Industrial Organization, 19, 739-762.

Nocke, V. and S.R. Yeaple (2008), An assignment theory of foreign direct investment, Review of Economic Studies, 75(2), 529-557 
Table 1 Number of firms and employment shares in Swedish manufacturing, 1993-2002.

\begin{tabular}{|c|c|c|c|c|c|c|c|c|c|}
\hline & \multicolumn{3}{|c|}{ Foreign MNEs } & \multicolumn{3}{|c|}{ Swedish MNEs } & \multicolumn{3}{c|}{ Swedish non-MNEs } \\
\hline Year & \multicolumn{2}{|c|}{ Firms } & Employment & \multicolumn{2}{c|}{ Firms } & Employment & \multicolumn{2}{c|}{ Firms } & Employment \\
\hline & \multicolumn{2}{|c|}{ Percent) } & Percent & \multicolumn{2}{c|}{ (Percent) } & Percent & \multicolumn{2}{c|}{ (Percent) } & Percent \\
\hline 1993 & 255 & $(20.5)$ & 21.0 & 421 & $(33.8)$ & 54.0 & 568 & $(45.7)$ & 25.0 \\
\hline 1994 & 274 & $(21.5)$ & 22.0 & 434 & $(34.1)$ & 56.7 & 565 & $(44.4)$ & 21.3 \\
\hline 1995 & 297 & $(22.2)$ & 22.9 & 427 & $(31.9)$ & 54.9 & 616 & $(46.0)$ & 22.2 \\
\hline 1996 & 336 & $(24.6)$ & 26.6 & 400 & $(29.3)$ & 51.1 & 631 & $(46.2)$ & 22.2 \\
\hline 1997 & 353 & $(25.6)$ & 26.3 & 400 & $(29.0)$ & 54.3 & 628 & $(45.5)$ & 19.4 \\
\hline 1998 & 392 & $(26.5)$ & 28.5 & 403 & $(27.3)$ & 51.5 & 683 & $(46.2)$ & 2.0 \\
\hline 1999 & 399 & $(27.6)$ & 34.7 & 410 & $(28.3)$ & 43.0 & 639 & $(44.1)$ & 22.3 \\
\hline 2000 & 422 & $(28.3)$ & 39.2 & 422 & $(28.3)$ & 39.5 & 649 & $(43.5)$ & 21.3 \\
\hline 2001 & 444 & $(29.8)$ & 45.0 & 408 & $(27.3)$ & 33.8 & 640 & $(42.9)$ & 21.2 \\
\hline 2002 & 447 & $(30.7)$ & 46.4 & 406 & $(27.9)$ & 34.5 & 601 & $(41.3)$ & 19.1 \\
\hline
\end{tabular}

Table 2 Development of MNEs and non-MNEs in Sweden by industry in percent. 1993, 2002

\begin{tabular}{|c|c|c|c|c|c|c|c|}
\hline & \multicolumn{3}{|c|}{1993} & \multicolumn{2}{c|}{2002} \\
\hline Industry & $\begin{array}{l}\text { sni92 } \\
\text { Codes }\end{array}$ & $\begin{array}{l}\text { Foreign } \\
\text { MNEs }\end{array}$ & $\begin{array}{l}\text { Swedish } \\
\text { MNEs }\end{array}$ & $\begin{array}{l}\text { Swedish } \\
\text { non-MNEs }\end{array}$ & $\begin{array}{l}\text { Foreign } \\
\text { MNEs }\end{array}$ & $\begin{array}{l}\text { Swedish } \\
\text { MNEs }\end{array}$ & $\begin{array}{l}\text { Swedish } \\
\text { non-MNEs }\end{array}$ \\
\hline Food \& beverages & 15 & 26,79 & 13,39 & 59,82 & 28,87 & 9,28 & 61,86 \\
\hline Tobacco products & 16 & 0,00 & 100,00 & 0,00 & 0,00 & 100,00 & 0,00 \\
\hline Textiles & 17 & 25,00 & 21,43 & 53,57 & 28,57 & 25,00 & 46,43 \\
\hline Apparel & 18 & 11,11 & 44,44 & 44,44 & 0,00 & 100,00 & 0,00 \\
\hline Leather, footwear & 19 & 0,00 & 100,00 & 0,00 & 0,00 & 0,00 & 100,00 \\
\hline Wood & 20 & 3,64 & 27,27 & 69,09 & 17,50 & 13,33 & 69,17 \\
\hline Paper \& pulp & 21 & 18,75 & 47,92 & 33,33 & 42,86 & 34,92 & 22,22 \\
\hline Publishing, printing & 22 & 9,62 & 17,31 & 73,08 & 13,19 & 21,53 & 65,28 \\
\hline Coke \& petroleum & 23 & 0,00 & 100,00 & 0,00 & 100,00 & 0,00 & 0,00 \\
\hline Chemicals & 24 & 44,78 & 35,82 & 19,40 & 66,67 & 17,33 & 16,00 \\
\hline Rubber \& plastic & 25 & 25,93 & 46,30 & 27,78 & 34,21 & 46,05 & 19,74 \\
\hline Non-metallic mineral & 26 & 19,30 & 52,63 & 28,07 & 55,81 & 13,95 & 30,23 \\
\hline Basic metals & 27 & 24,44 & 46,67 & 28,89 & 53,06 & 22,45 & 24,49 \\
\hline Fabricated metal & 28 & 11,67 & 34,17 & 54,17 & 17,87 & 29,47 & 52,66 \\
\hline Machinery, equipm. & 29 & 23,12 & 46,24 & 30,64 & 32,38 & 36,67 & 30,95 \\
\hline Electrical \& optical & 30 & 62,50 & 12,50 & 25,00 & 9,09 & 27,27 & 63,64 \\
\hline Electrical machinery & 31 & 45,10 & 15,69 & 39,22 & 42,86 & 28,57 & 28,57 \\
\hline Radio TV & 32 & 29,17 & 37,50 & 33,33 & 27,59 & 41,38 & 31,03 \\
\hline Medical instruments & 33 & 25,71 & 57,14 & 17,14 & 53,33 & 31,11 & 15,56 \\
\hline Motor vehicles & 34 & 18,00 & 40,00 & 42,00 & 32,94 & 40,00 & 27,06 \\
\hline Other transport eq. & 35 & 34,62 & 34,62 & 30,77 & 29,03 & 25,81 & 45,16 \\
\hline Other manufacturing & 36 & 10,77 & 33,85 & 55,38 & 21,79 & 34,62 & 43,59 \\
\hline \hline
\end{tabular}

Notes: The sample is truncated at 50 employees. Source: Statistics Sweden. 
Table 3 Characteristics of MNEs (foreign and Swedish) and non-MNEs in Swedish manufacturing 2002.

\begin{tabular}{|c|c|c|c|c|c|}
\hline & \multicolumn{5}{|c|}{2002} \\
\hline Variables & $\begin{array}{c}\text { Foreign } \\
\text { MNEs }\end{array}$ & $\begin{array}{c}\text { Swedish } \\
\text { MNEs }\end{array}$ & $\begin{array}{c}\text { Difference foreign } \\
\text { MNEs and Swedish } \\
\text { MNEs (t-ratio) }\end{array}$ & $\begin{array}{c}\text { Non- } \\
\text { MNEs }\end{array}$ & $\begin{array}{c}\text { Difference Swedish } \\
\text { MNEs and non-MNEs } \\
\text { (t-ratio) }\end{array}$ \\
\hline R\&D intensity & 28.5 & 23.4 & $5.1(2.19)$ & 8.8 & $14.6(8.41)$ \\
\hline Employment & 408 & 334 & $74(1.05)$ & 125 & $209(6.31)$ \\
\hline Sales & 711 & 536 & $175(1.12)$ & 151 & $385(5.23)$ \\
\hline Labor productivity & 452 & 438 & $14(0.68)$ & 364 & $74(5.45)$ \\
\hline Capital-labor ratio & 220 & 143 & $77(1.43)$ & 51 & $92(3.51)$ \\
\hline Skill intensity & 20.1 & 18.7 & $1.4(1.44)$ & 14.2 & $4.5(5.29)$ \\
\hline Average wage & 204 & 197 & $7(2.73)$ & 179 & $18(7.33)$ \\
\hline
\end{tabular}

Notes: Labor productivity is measured as value added, deflated by the industry producer price index, per employee. Physical capital is here measured by the book value of machinery and buildings, per employee and human capital intensity is measured by the proportion of employees with more than upper secondary education.

Table 4 Frequency of foreign acquisitions by year 1993-2002

\begin{tabular}{|c|c|c|c|c|c|c|c|c|c|c|}
\hline & 1994 & 1995 & 1996 & 1997 & 1998 & 1999 & 2000 & 2001 & 2002 & $94-02$ \\
\hline Acquired Swedish MNE & 1 & 5 & 26 & 3 & 5 & 10 & 6 & 3 & 9 & 68 \\
\hline Acquired Swedish Non-MNE & 18 & 16 & 20 & 11 & 11 & 14 & 14 & 39 & 16 & 159 \\
\hline Total & 19 & 21 & 46 & 14 & 16 & 24 & 20 & 42 & 25 & 227 \\
\hline
\end{tabular}


Table 5 Pre- and post acquisition differences in means between acquired and non-acquired firms.

\begin{tabular}{|c|c|c|c|c|}
\hline \multirow[t]{3}{*}{ Variable } & $\mathrm{T}-1$ & $\mathrm{~T}+1$ & $\mathrm{~T}+2$ & $\mathrm{~T}+3$ \\
\hline & Difference & Difference & Difference & Difference \\
\hline & (t-ratio) & (t-ratio) & (t-ratio) & (t-ratio) \\
\hline \multirow[t]{2}{*}{ R\&D intensity } & 0.9 & 0.9 & 1.3 & 1.3 \\
\hline & $(3.37)^{* * *}$ & $(2.73)^{* * *}$ & $(3.76)^{* * *}$ & $(3.45)^{* * *}$ \\
\hline \multirow[t]{2}{*}{ Employment } & 314 & 401 & 416 & 422 \\
\hline & $(2.94)^{* * *}$ & $(3.61)^{* * *}$ & $(3.69)^{* * *}$ & $(3.68)^{* * *}$ \\
\hline \multirow[t]{2}{*}{ Sales } & 832 & 1086 & 743 & 713 \\
\hline & $(3.12)^{* * *}$ & $(2.92)^{* * *}$ & $(1.75)^{*}$ & $(1.44)$ \\
\hline \multirow[t]{2}{*}{ Labor productivity } & 66 & 48 & 67 & 63 \\
\hline & $(3.30)^{* * *}$ & $(2.26)^{* *}$ & $(3.03)^{* * *}$ & $(2.49)^{* *}$ \\
\hline \multirow[t]{2}{*}{ Capital-labor ratio } & 268 & 369 & 357 & 373 \\
\hline & $(5.27)^{* * *}$ & $(6.00)^{* * *}$ & $(5.31)^{* * *}$ & $(5.10)^{* * *}$ \\
\hline \multirow[t]{2}{*}{ Skill intensity } & 3.5 & 2.8 & 2.7 & 2.4 \\
\hline & $(3.09)^{* * *}$ & $(2.40)^{* *}$ & $(2.23)^{* *}$ & $(1.89)^{*}$ \\
\hline \multirow[t]{2}{*}{ Average wage } & 13.9 & 13.6 & 13.8 & 12.7 \\
\hline & $(4.96)^{* * *}$ & $(4.71)^{* * *}$ & $(4.70)^{* * *}$ & $(4.18)^{* * *}$ \\
\hline \multicolumn{5}{|l|}{ Observations } \\
\hline Acquired firms & 89 & 89 & 89 & 89 \\
\hline Non- Acquired firms & 4,095 & 4,095 & 4,095 & 4,095 \\
\hline
\end{tabular}

Notes: Shipment is in million SEK. Wages, capital-labor ratios and labor productivity, value added per employee, are in thousand SEK. R\&D intensity and Skill intensity, share of employees with a post-secondary education, are in percentages. 
Table 6 Post-acquisition effect on R\&D intensity unmatched sample, OLS and Fixed effect model.

\begin{tabular}{|c|c|c|c|c|c|c|}
\hline & \multicolumn{2}{|c|}{$\Delta R \& D$ intensity ${ }_{t+1}$} & \multicolumn{2}{|c|}{$\Delta R \& D$ intensity ${ }_{t+2}$} & \multicolumn{2}{|c|}{$\Delta R \& D$ intensity ${ }_{t+3}$} \\
\hline & OLS & $\mathrm{FE}$ & OLS & $\mathrm{FE}$ & OLS & FE \\
\hline & (i) & (ii) & (iii) & (iv) & (v) & (vi) \\
\hline Foreign acquired & 0.049 & 0.054 & 0.074 & 0.080 & 0.054 & 0.051 \\
\hline & $(4.16)^{\mathrm{a}}$ & $(4.78)^{a}$ & $(4.51)^{\mathrm{a}}$ & $(4.86)^{\mathrm{a}}$ & $(3.30)^{\mathrm{a}}$ & $(3.27)^{\mathrm{a}}$ \\
\hline Observation & 9,612 & 9,612 & 8,266 & 8,266 & 6,940 & 6,940 \\
\hline $\mathrm{R}^{2}$ & 0.024 & & 0.034 & & 0.043 & \\
\hline $\mathrm{R}^{2}$ Within & & 0.016 & & 0.017 & & 0.017 \\
\hline $\mathrm{R}^{2}$ Between & & 0.009 & & 0.001 & & 0.001 \\
\hline $\mathrm{R}^{2}$ Overall & & 0.016 & & 0.014 & & 0.013 \\
\hline
\end{tabular}

Notes: In estimations where OLS is used year and industry dummies are controlled for. Industries are defined at the SNI92 3-digit level (99 industries). Standard errors within the parenthesis. a, b and c indicate significance at 1, 5 and 10 percent levels, respectively.

Table 7 Post-acquisition effect on R\&D intensity, instrumental variable approach.

\begin{tabular}{|c|c|c|c|}
\hline & $\begin{array}{c}\Delta R \& D \\
\text { intensity }_{t+1}\end{array}$ & $\begin{array}{c}\Delta R \& D \\
\text { intensity }_{t+2}\end{array}$ & $\begin{array}{c}\Delta R \& D \\
\text { intensity }_{t+3}\end{array}$ \\
\hline & (i) & (ii) & (iii) \\
\hline Foreign acquired & 0.306 & 0.222 & 0.418 \\
\hline & $(3.15)^{\mathrm{a}}$ & $(1.56)$ & $(2.53)^{b}$ \\
\hline Observation & 9,612 & 8,266 & 6,940 \\
\hline F-test (first-stage reg.) & 0.000 & 0.000 & 0.000 \\
\hline Sargan test (p-value) & 0.132 & 0.020 & 0.002 \\
\hline Hausman test (p-value) & 0.000 & 0.001 & 0.000 \\
\hline
\end{tabular}

Notes: In all columns year and industry dummies are controlled for. Industries are defined at the SNI92 3-digit level (99 industries). Standard errors within the parenthesis are bootstrapped. a, b and c indicate significance at 1,5 and 10 percent levels, respectively. Estimations in Model (1) use an instrument generated from the probit regression reported in Table A1, column (i).

Table 8 Post-acquisition effect on R\&D intensity, matched sample, OLS and Fixed effect model.

\begin{tabular}{|c|c|c|c|c|c|c|}
\hline & \multicolumn{2}{|c|}{$\Delta R \& D$ intensity ${ }_{t+1}$} & \multicolumn{2}{|c|}{$\Delta R \& D$ intensity $t_{t+2}$} & \multicolumn{2}{|c|}{$\Delta R \& D$ intensity ${ }_{t+3}$} \\
\hline & OLS & FE & OLS & FE & OLS & FE \\
\hline & (i) & (ii) & (iii) & (iv) & (v) & (vi) \\
\hline Foreign acquired & $\begin{array}{c}0.048 \\
(3.90)^{\mathrm{a}}\end{array}$ & $\begin{array}{c}0.052 \\
(4.32)^{\mathrm{a}}\end{array}$ & $\begin{array}{c}0.081 \\
(4.82)^{\mathrm{a}}\end{array}$ & $\begin{array}{c}0.077 \\
(4.59)^{\mathrm{a}}\end{array}$ & $\begin{array}{c}0.065 \\
(3.90)^{\mathrm{a}}\end{array}$ & $\begin{array}{c}0.059 \\
(3.67)^{\mathrm{a}}\end{array}$ \\
\hline Observation & 3,069 & 3,069 & 2,644 & 2,644 & 2,215 & 2,215 \\
\hline $\mathrm{R}^{2}$ & 0.040 & & 0.048 & & 0.065 & \\
\hline $\mathrm{R}^{2}$ Within & & 0.015 & & 0.017 & & 0.012 \\
\hline $\mathrm{R}^{2}$ Between & & 0.064 & & 0.016 & & 0.010 \\
\hline $\mathrm{R}^{2}$ Overall & & 0.018 & & 0.018 & & 0.013 \\
\hline
\end{tabular}

Notes: See Table 6. 
Table 9 Post-acquisition effect on R\&D intensity, DiD Matching estimator

\begin{tabular}{cccc}
\hline \multirow{2}{*}{$y_{t+s}-y_{t-1}$} & \multicolumn{2}{c}{ Foreign acquired } \\
\cline { 3 - 4 }$\Delta \mathrm{R} \& \mathrm{D}$ intensity & $s=1$ & 0.036 & T-stat \\
& $s=2$ & 0.022 & $(2.51)^{* * *}$ \\
& $s=3$ & 0.016 & $(1.60)$ \\
\hline \hline
\end{tabular}

Table 10 Post-acquisition effect on R\&D intensity in different targets, instrumental variable approach.

\begin{tabular}{|c|c|c|c|}
\hline & $\begin{array}{c}\Delta \mathbf{R} \& \mathbf{D} \\
\text { intensity }_{\mathbf{t}+\mathbf{1}}\end{array}$ & $\begin{array}{c}\Delta \mathbf{R} \& \mathbf{D} \\
\text { intensity }_{\mathbf{t}+\mathbf{2}}\end{array}$ & $\begin{array}{c}\Delta \mathbf{R} \& \mathbf{D} \\
\text { intensity }_{\mathbf{t}+\mathbf{3}}\end{array}$ \\
\hline & $(\mathrm{i})$ & $(\mathrm{ii})$ & $(\mathrm{iii})$ \\
\hline Acquired & 0.339 & 0.188 & 0.444 \\
\hline Swedish MNE & $(2.42)^{\mathrm{b}}$ & $(1.12)$ & $(2.25)^{\mathrm{b}}$ \\
\hline Acquired & 0.372 & 1.067 & 1.531 \\
\hline Swedish non-MNE & $(2.61)^{\mathrm{a}}$ & $(2.54)^{\mathrm{b}}$ & $(2.79)^{\mathrm{b}}$ \\
\hline Observation & 9,612 & 8,266 & 6,940 \\
\hline F-test (first-stage reg.) & & & \\
\hline Sargan test (p-value) & & & \\
\hline Hausman test (p-value) & & & \\
\hline
\end{tabular}

Notes: See Table 7.

Table 11 Post-acquisition effect on R\&D intensity in different targets, matched sample, OLS and Fixed effect model.

\begin{tabular}{|c|c|c|c|c|c|c|}
\hline & \multicolumn{2}{|c|}{$\Delta R \& D$ intensity $t_{t+1}$} & \multicolumn{2}{|c|}{$\Delta R \& D$ intensity $t_{t+2}$} & \multicolumn{2}{|c|}{$\Delta R \& D$ intensity $t_{t+3}$} \\
\hline & OLS & FE & OLS & FE & OLS & FE \\
\hline & (i) & (ii) & (iii) & (iv) & $(\mathrm{v})$ & (vi) \\
\hline Acquired & 0.013 & 0.025 & 0.093 & 0.089 & 0.068 & 0.079 \\
\hline Swedish MNE & $(0.78)$ & $(1.63)$ & $(3.03)^{\mathrm{a}}$ & $(2.86)^{\mathrm{a}}$ & $(2.11)^{b}$ & $(2.53)^{b}$ \\
\hline Acquired & 0.062 & 0.063 & 0.074 & 0.071 & 0.061 & 0.061 \\
\hline Swedish non-MNE & $(3.97)^{\mathrm{a}}$ & $(4.09)^{\mathrm{a}}$ & $(3.79)^{\mathrm{a}}$ & $(3.67)^{\mathrm{a}}$ & $(2.88)^{\mathrm{a}}$ & $(3.15)^{\mathrm{a}}$ \\
\hline Observation & 3,069 & 3,069 & 2,644 & 2,644 & 2,215 & 2,215 \\
\hline $\mathrm{R}^{2}$ & 0.041 & & 0.048 & & 0.065 & \\
\hline $\mathrm{R}^{2}$ Within & & 0.016 & & 0.017 & & 0.012 \\
\hline $\mathrm{R}^{2}$ Between & & 0.060 & & 0.017 & & 0.012 \\
\hline $\mathrm{R}^{2}$ Overall & & 0.018 & & 0.018 & & 0.014 \\
\hline
\end{tabular}

Notes: See Table 8. 
Table 12 Post-acquisition effect on R\&D intensity in different targets, DiD Matching estimator

\begin{tabular}{|c|c|c|c|c|c|}
\hline \multirow[b]{2}{*}{$y_{t+s}-y_{t-1}$} & & \multicolumn{2}{|c|}{$\begin{array}{c}\text { Acquired Swedish } \\
\text { MNE }\end{array}$} & \multicolumn{2}{|c|}{$\begin{array}{l}\text { Acquired Swedish } \\
\text { non-MNE }\end{array}$} \\
\hline & & DiD & T-stat & DiD & T-stat \\
\hline \multirow[t]{3}{*}{$\Delta \mathrm{R} \& \mathrm{D}$ intensity } & $s=1$ & 0.023 & $(2.45)^{* *}$ & 0.064 & $(2.98)^{* * *}$ \\
\hline & $s=2$ & 0.046 & $(3.44)^{* * *}$ & 0.095 & $(3.37)^{* * *}$ \\
\hline & $s=3$ & 0.052 & $(3.18)^{* * *}$ & 0.094 & $(2.82)^{* * *}$ \\
\hline
\end{tabular}




\section{Appendix}

\section{Details on the probit estimation}

The predicted value of the acquisition dummy is generated using the probit model described in equation (4). To check the robustness of our result we estimate two alternative specification to generate the predicted probability. The results in Table A1 indicate that the more productive, skilland capital intensive the domestic firms are, the more likely they are being acquired by foreign MNEs. Moreover, firms in industries with a large foreign presence are more likely to be taken over.

Table A1 The Probit model. Probability of foreign acquisition

\begin{tabular}{|c|c|c|}
\hline Variables & Model (1) & Model (2) \\
\hline \multirow[t]{2}{*}{ Labor productivity } & 0.144 & 0.194 \\
\hline & $(1.98)^{b}$ & $(2.88)^{\mathrm{a}}$ \\
\hline \multirow[t]{2}{*}{ Relative employment } & -0.002 & -0.001 \\
\hline & $(0.54)$ & $(0.04)$ \\
\hline \multirow[t]{2}{*}{ Skill intensity } & 0.802 & 0.771 \\
\hline & $(3.66)^{\mathrm{a}}$ & $(3.56)^{\mathrm{a}}$ \\
\hline \multirow[t]{2}{*}{ Age } & -0.087 & -0.089 \\
\hline & $(5.70)^{\mathrm{a}}$ & $(5.79)^{\mathrm{a}}$ \\
\hline \multirow[t]{2}{*}{$(\text { Age })^{2}$} & 0.002 & 0.002 \\
\hline & $(4.87)^{\mathrm{a}}$ & $(5.04)^{\mathrm{a}}$ \\
\hline \multirow[t]{2}{*}{ Foreign presence } & 0.097 & 0.099 \\
\hline & $(3.22)^{\mathrm{a}}$ & $(3.35)^{\mathrm{a}}$ \\
\hline \multirow[t]{2}{*}{ Capital intensity } & 0.054 & \\
\hline & $(2.47)^{\mathrm{a}}$ & \\
\hline \multirow[t]{2}{*}{ Sales } & & 0.015 \\
\hline & & $(1.58)$ \\
\hline Year dummies & Yes & Yes \\
\hline Pseudo $\mathrm{R}^{2}$ & 0.058 & 0.056 \\
\hline LR chi2 & 108.61 & 104.19 \\
\hline Observations & 9,612 & 9,612 \\
\hline
\end{tabular}

Notes: The dependent variable $A F_{i t}=1$ if a domestically owned firm in year $t-1$ becomes foreign owned in year $t$. $\mathrm{z}$ statistics is within parentheses. The explanatory variables are, apart from age age ${ }^{2}$, firm specific characteristics in year $t-1$. Relative employment is firm employment relative to mean firm employment at the industry level. Labor productivity is value added per employee and skill intensity is the share of employees with post-secondary education at the firm level. The share of foreign employment at industry the level (SNI92 2-digit level) is used as a proxy for foreign presence. a, b and c indicate significance at 1, 5 and 10 percent levels, respectively. 
Table A2 Description of the estimated propensity score

\begin{tabular}{ccccc}
\hline \multicolumn{3}{c}{ Model 1 } & \multicolumn{2}{c}{ Model 2 } \\
\hline & Percentiles & Smallest & Percentiles & Smallest \\
$5 \%$ & 0.00608 & 0.00184 & 0.00555 & 0.00207 \\
$10 \%$ & 0.00834 & 0.00214 & 0.00861 & 0.00220 \\
$25 \%$ & 0.00986 & 0.00223 & 0.01018 & 0.00235 \\
& 0.01335 & 0.00235 & 0.01348 & 0.00242 \\
$50 \%$ & 0.01915 & & & \\
& & Largest & 0.01922 & Largest \\
$75 \%$ & 0.02851 & 0.14298 & 0.02850 & 0.14217 \\
$90 \%$ & 0.04348 & 0.14678 & 0.04289 & 0.14663 \\
$95 \%$ & 0.05456 & 0.15474 & 0.05385 & 0.15500 \\
$99 \%$ & 0.08399 & 0.17731 & 0.08247 & 0.17733 \\
& & & & \\
Observation & 9,612 & 9,612 & \\
Sum of Wgt. & 9,612 & 0.012 & 0.01549 \\
Mean & 0.02360 & 0.00024 \\
Std. Dev. & 0.01582 & 2.27748 \\
Variance & 0.00025 & 11.3516 \\
Skewness & 2.29449 & &
\end{tabular}

Note: The common support option has been selected.

Table A3 Test of balancing property of the propensity score

\begin{tabular}{ccccc}
\hline & \multicolumn{2}{c}{ Model 1 } & \multicolumn{2}{c}{ Model 2 } \\
\hline Acquisition & $\mathbf{0}$ & $\mathbf{1}$ \\
Inferior of & $\mathbf{0}$ & $\mathbf{1}$ & & \\
block of pscore & & 101 & 6,403 & 101 \\
0 & 6,476 & 71 & 2,422 & 72 \\
0.025 & 2,324 & 48 & 530 & 50 \\
0.05 & 552 & 7 & 30 & 4 \\
0.1 & 33 & & & 227 \\
& & 227 & 9,385 &
\end{tabular}

Note: The balancing property is satisfied. 
Table A4 Robustness check: Post-acquisition effect on R\&D intensity, alternative instrument.

\begin{tabular}{|c|c|c|c|}
\hline & $\begin{array}{c}\Delta \mathbf{R} \& \mathbf{D} \\
\text { intensity }_{\mathbf{t}+\mathbf{1}}\end{array}$ & $\begin{array}{c}\Delta \mathbf{R} \& \mathbf{D} \\
\text { intensity }_{\mathbf{t}+\mathbf{2}}\end{array}$ & $\begin{array}{c}\Delta \mathbf{R} \& \mathbf{D} \\
\text { intensity }_{\mathbf{t}+\mathbf{3}}\end{array}$ \\
\hline & (i) & (ii) & (iii) \\
\hline Foreign acquired & 0.168 & 0.165 & 0.424 \\
\hline & $(1.76)^{\mathrm{C}}$ & $(1.17)$ & $(2.58)^{\mathrm{b}}$ \\
\hline Observation & 9,612 & 8,266 & 6,940 \\
\hline F-test (first-stage reg.) & 0.000 & 0.000 & 0.000 \\
\hline Sargan test (p-value) & 0.051 & 0.297 & 0.002 \\
\hline Hausman test (p-value) & 0.000 & 0.000 & 0.001 \\
\hline
\end{tabular}

Notes: See Table 7. Estimations in Model (2) use an instrument generated from the probit regression reported in Table A1, column (ii).

Table A5 Post-acquisition effect on R\&D intensity in different targets, matched sample, OLS and Fixed effect model. Balanced sample.

\begin{tabular}{|c|c|c|c|c|c|c|}
\hline & \multicolumn{2}{|c|}{$\Delta R \& D$ intensity ${ }_{t+1}$} & \multicolumn{2}{|c|}{$\Delta R \& D$ intensity $t_{t+2}$} & \multicolumn{2}{|c|}{$\Delta R \& D$ intensity ${ }_{t+3}$} \\
\hline & OLS & FE & OLS & $\mathrm{FE}$ & OLS & FE \\
\hline & (i) & (ii) & (iii) & (iv) & (v) & (vi) \\
\hline Acquired & 0.012 & 0.023 & 0.069 & 0.067 & 0.068 & 0.079 \\
\hline Swedish MNE & $(0.62)$ & $(1.46)$ & $(2.40)^{b}$ & $(2.36)^{\mathrm{a}}$ & $(2.11)^{b}$ & $(2.53)^{b}$ \\
\hline Acquired & 0.052 & 0.052 & 0.079 & 0.077 & 0.061 & 0.061 \\
\hline Swedish non-MNE & $(2.78)^{\mathrm{a}}$ & $(2.79)^{\mathrm{a}}$ & $(3.46)^{\mathrm{a}}$ & $(3.54)^{\mathrm{a}}$ & $(2.88)^{\mathrm{a}}$ & $(3.15)^{\mathrm{a}}$ \\
\hline Observation & 2,215 & 2,215 & 2,215 & 2,215 & 2,215 & 2,215 \\
\hline $\mathrm{R}^{2}$ & 0.040 & & 0.051 & & 0.065 & \\
\hline $\mathrm{R}^{2}$ Within & & 0.013 & & 0.016 & & 0.012 \\
\hline $\mathrm{R}^{2}$ Between & & 0.037 & & 0.012 & & 0.012 \\
\hline $\mathrm{R}^{2}$ Overall & & 0.015 & & 0.017 & & 0.014 \\
\hline
\end{tabular}

Notes: See Table 6.

Table A6 Average effect of foreign acquisition on growth rate of R\&D intensity in acquired Swedish MNEs and non-MNEs. Balanced sample.

\begin{tabular}{llccccc}
\hline & & \multicolumn{2}{c}{$\begin{array}{c}\text { Acquired Swedish } \\
\text { MNE }\end{array}$} & & \multicolumn{2}{c}{$\begin{array}{c}\text { Acquired Swedish } \\
\text { non-MNE }\end{array}$} \\
\cline { 3 - 4 }$y_{t+s}-y_{t-1}^{*}$ & & DiD & T-stat & & DiD & T-stat \\
\hline$\Delta$ R\&D intensity & $s=1$ & 0.046 & $(4.22)^{* *}$ & & 0.046 & $(153)$ \\
& $s=2$ & 0.053 & $(3.55)^{* * *}$ & & 0.086 & $(2.66)^{* * *}$ \\
& $s=3$ & 0.052 & $(3.18)^{* * *}$ & & 0.094 & $(2.82)^{* * *}$ \\
\hline \hline
\end{tabular}

